\title{
SPF-32629 A and B, Novel Human Chymase Inhibitors Produced by Penicillium sp.
}

\author{
Takuro Shimatani ${ }^{\dagger}$, Nobuo Hosotani ${ }^{\dagger}$, Masako Ohnishi ${ }^{\dagger \dagger}$, Kazuo Kumagai ${ }^{\dagger}$, Ikutaro Saji ${ }^{\dagger^{\dagger \dagger}}$
}

Received: September 30, 2005 / Accepted: December 15, 2005

(C) Japan Antibiotics Research Association

\begin{abstract}
Two new human chymase inhibitors, SPF32629A and B, were isolated from the cultured broth of Penicillium sp. SPF-32629. These structures were determined by spectroscopic methods and identified as new pyridone compounds. SPF-32629B was the carboxylated derivative of SPF-32629A. SPF-32629A and B specifically inhibited human chymase among four serine proteases tested with the $\mathrm{IC}_{50}$ of 0.25 and $0.42 \mu \mathrm{g} / \mathrm{ml}$, respectively.
\end{abstract}

Keywords chymase inhibitor, pyridone, Penicillium, chymostatin, SPF-32629 A and B

\section{Introduction}

Human chymase (EC 3.4.21.39) is a chymotrypsin-like serine protease stored in the secretory granules of mast cells [1]. Chymase has been implicated in the vascular remodeling by converting angiotensin I to angiotensin II in the cardiovascular tissues $[2,3]$. Chymase is also shown to be involved in cholesterol efflux from macrophage foam cells by depletion of pre $\beta 1 \mathrm{LpA} 1$ [4] and the degranulation of skin mast cells by histamine release from mast cells [5]. It has been reported to have the abilities of processing several physiological preproteins such as big-endothelin [6], precursor interleukin-1 $\beta$ [7] and interstitial procollagenase [8]. Therefore, chymase inhibitors are considered to be useful as therapeutic agents for cardiovascular diseases, arteriosclerosis and skin inflammation. Soybean trypsin inhibitor and chymostatin, which are serine protease inhibitors from natural products, are known to inhibit human chymase, with little specificity [2]. Recently SF2809 compounds have been isolated as specific human chymase inhibitors from microbial sources $[9,10]$.

In search for human chymase inhibitors from microorganisms, we isolated two novel compounds, SPF32629A (1) and B (2) (Fig. 1), from the cultured broth of a fungal strain SPF-32629. In this paper, we describe the

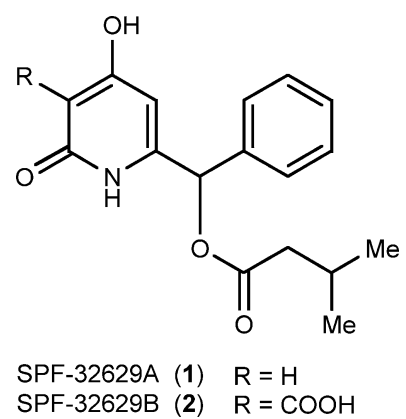

Fig. 1 Structures of SPF-32629A (1) and SPF-32629B (2).
T. Shimatani (Corresponding author), N. Hosotani, K. Kumagai, I. Saji: Exploratory Research Group, Research Division, Sumitomo Pharmaceuticals Co., Ltd., 4-2-1 Takatsukasa, Takarazuka, Hyogo 665-0051, Japan.

E-mail: takuro-shimatani@ds-pharma.co.jp

M. Ohnishi: Discovery Research Laboratories II, Research Division, Sumitomo Pharmaceuticals Co., Ltd., 3-1-98 Kasugadenaka, Konohana-ku, Osaka 554-0022, Japan
${ }^{\dagger}$ Present address: Dainippon Sumitomo Pharma Co., Ltd., 4-2-1 Takatsukasa, Takarazuka, Hyogo 665-0051, Japan

${ }^{\dagger}$ Present address: Dainippon Sumitomo Pharma Co., Ltd., 33-94 Enoki, Suita, Osaka 564-0053, Japan

${ }^{\dagger \dagger}$ Present address: Dainippon Sumitomo Pharma Co., Ltd., 3-198 Kasugadenaka, Konohana-ku, Osaka 554-0022, Japan 
taxonomy and fermentation of the producing strain and the isolation, structure elucidation and biological activities of these two compounds.

\section{Materials and Methods}

\section{General}

UV spectra were recorded with a Hitachi U-2000 spectrophotometer. IR spectra were recorded with a PerkinElmer 1600 series FT-IR spectrometer. FAB-MS spectra were obtained with a JEOL JMS-SX102A spectrometer. Optical rotations were measured with a Perkin-Elmer Model 241 polarimeter in a $10 \mathrm{~cm}$ cell. NMR spectra were recorded with a JEOL JNM $\alpha-500$ spectrometer and the chemical shifts are given in ppm referenced to $\mathrm{CDCl}_{3}$ as $7.25 \mathrm{ppm}\left({ }^{1} \mathrm{H}\right)$ and $77.0 \mathrm{ppm}\left({ }^{13} \mathrm{C}\right)$ and to acetone- $d_{6}$ as $2.05 \mathrm{ppm}\left({ }^{1} \mathrm{H}\right)$ and $29.8 \mathrm{ppm}\left({ }^{13} \mathrm{C}\right)$.

\section{Microorganism}

The fungal strain SPF-32629 was isolated from a soil sample collected in Saga Prefecture, Japan. The strain has been deposited at the International Patent Organism Depositary, the National Institute of Advanced Industrial Science and Technology, Japan under the accession number FERM P-18906.

\section{Taxonomy}

Taxonomic studies of the strain SPF-32629 were done according to the methods of Pitt [11]. For the evaluation of cultural characteristics, Czapek yeast extract agar (CYA, $\mathrm{K}_{2} \mathrm{HPO}_{4} 0.1 \%$, yeast extract $0.5 \%$, sucrose $3 \%, \mathrm{NaNO}_{3}$ $0.3 \%, \mathrm{KCl} 0.05 \%, \mathrm{MgSO}_{4} \cdot 7 \mathrm{H}_{2} \mathrm{O} 0.05 \%, \mathrm{FeSO}_{4} \cdot 7 \mathrm{H}_{2} \mathrm{O}$ $0.001 \%$, agar $1.5 \%$ ), malt extract agar (MEA, malt extract $2 \%$, peptone $0.1 \%$, glucose $2 \%$, agar $1.5 \%$ ), $25 \%$ glycerol nitrate agar $\left(\mathrm{G} 25 \mathrm{~N}, \mathrm{~K}_{2} \mathrm{HPO}_{4} 0.075 \%\right.$, yeast extract $0.37 \%$, glycerol $25 \%, \mathrm{NaNO}_{3} 0.23 \%, \mathrm{KCl} 0.038 \%, \mathrm{MgSO}_{4} \cdot 7 \mathrm{H}_{2} \mathrm{O}$ $0.038 \%, \mathrm{FeSO}_{4} \cdot 7 \mathrm{H}_{2} \mathrm{O} 0.0008 \%$, agar $1.2 \%$ ), yeast extractsoluble starch agar (YSA, yeast extract $0.2 \%$, soluble starch $1 \%$, agar $1.5 \%$ ), potato dextrose agar (PDA, Nihon Pharmaceutical, Japan) and Oatmeal agar (OA, ISP medium No. 3, Nihon Pharmaceutical, Japan) were used. Colors were determined by using the Color Tone Manual [12]. Morphology was observed under an optical microscope.

\section{Fermentation}

A slant culture of the strain SPF-32629 was inoculated into a 500-ml Sakaguchi flask containing $80 \mathrm{ml}$ of liquid medium composed of glucose $2 \%$, sucrose $5 \%$, cotton seed flour $2 \%, \mathrm{NaNO}_{3} 0.1 \%$, L-histidine $0.1 \%, \mathrm{~K}_{2} \mathrm{HPO}_{4} 0.05 \%$,
$\mathrm{KCl} 0.07 \%, \mathrm{MgSO}_{4} \cdot 7 \mathrm{H}_{2} \mathrm{O} 0.0014 \%, \mathrm{pH} 7.0$, and cultured for 3 days at $27^{\circ} \mathrm{C}$ with reciprocal shaking at $130 \mathrm{rpm}$. An aliquot of $7 \mathrm{ml}$ of this seed culture was transferred into 2liter Sakaguchi flasks containing $300 \mathrm{ml}$ of the same medium, and cultured for 11 days at $27^{\circ} \mathrm{C}$ with reciprocal shaking at $115 \mathrm{rpm}$.

\section{HPLC Analysis}

The cultured broth $(10 \mathrm{ml})$ was extracted with $8 \mathrm{ml}$ of $n$ $\mathrm{BuOH}$. The extracts were evaporated to dryness in vacuo, and the residues were dissolved in $1 \mathrm{ml}$ of $\mathrm{MeOH}$. Samples $(2 \mu \mathrm{l})$ were analyzed by reversed-phase HPLC using a Wakopak Wakosil-II5C18RS column $(4.6 \times 150 \mathrm{~mm}$, Wako Pure Chemical Industry, Japan) with aqueous $0.05 \%$ TFA acetonitrile (60:40 to $20: 80$ in 20 minutes) at a flow rate of $1.0 \mathrm{ml} /$ minute, and detection of UV absorption at $254 \mathrm{~nm}$. Compounds $\mathbf{1}$ and $\mathbf{2}$ were eluted at 6.6 and 13.9 minutes, respectively. The optical purity of compounds 1 and 2 was analyzed by four types of chiral HPLC columns $(4.6 \times 250 \mathrm{~mm})$; Chiralpak AD-H, Chiralpak AS-H, Chiralcel OD-H and Chiralcel OJ-H (Daicel Chemical Industry, Japan), on four solvent systems ( $n$-hexane - EtOH, $n$-hexane - $i$ - $\mathrm{PrOH}, n$-hexane - EtOH - $\mathrm{AcOH}$ and $n$-hexane $i$-PrOH $-\mathrm{AcOH}$ ) at a flow rate of $1.0 \mathrm{ml} /$ minute, and detection of UV absorption at $254 \mathrm{~nm}$.

\section{Assay of Serine Protease Inhibition}

Substrates and enzymes used were as follows: $N$-succinylAla-Ala-Pro-Phe-MCA (Peptide Institute Inc., Japan) for human skin chymase (Elastin Product, USA), human pancreatic chymotrypsin (Athens Research Technology, USA) and human leukocyte cathepsin G (MP Biomedicals, USA) [13]; $N$-methoxysuccinyl-Ala-Ala-Pro-Val-MCA (Peptide Institute Inc., Japan) for human leukocyte elastase (Athens Research Technology, USA) [14]. Enzymatic reactions were carried out in the following buffers: $50 \mathrm{mM}$ Tris-HCl buffer ( $\mathrm{pH} 8.0$ ) containing $3 \mathrm{M} \mathrm{NaCl}, 0.01 \%$ bovine serum albumin, $150 \mathrm{ng} / \mathrm{ml}$ enzyme and $100 \mu \mathrm{M}$ substrate for chymase; $50 \mathrm{mM}$ Tris-HCl buffer ( $\mathrm{pH} 8.0)$ containing $120 \mathrm{mM} \mathrm{NaCl}, 150 \mathrm{ng} / \mathrm{ml}$ enzyme and $100 \mu \mathrm{M}$ substrate for chymotrypsin; $100 \mathrm{mM}$ Tris- $\mathrm{HCl}$ buffer $(\mathrm{pH}$ 7.5 ) containing $1.6 \mathrm{M} \mathrm{NaCl}, 1 \mu \mathrm{g} / \mathrm{ml}$ enzyme and $100 \mu \mathrm{M}$ substrate for cathepsin G; $50 \mathrm{mM}$ Tris-HCl buffer (pH 7.0) containing $2 \mathrm{mM} \mathrm{CaCl}_{2}, 300 \mathrm{ng} / \mathrm{ml}$ enzyme and $100 \mu \mathrm{M}$ substrate for elastase. Test samples $(1 \mu \mathrm{l})$ dissolved in DMSO were added to each reaction mixture $(99 \mu \mathrm{l})$ in 96 well microplates and incubated for 2 hours at $37^{\circ} \mathrm{C}$ except for chymase assay, which was carried out for 5 hours at room temperature.

Serine protease activities were measured by monitoring spectrofluorometrically the release of AMC (7-amino-4- 
methyl-coumarine) at wavelengths of Ex $355 \mathrm{~nm} / \mathrm{Em}$ $460 \mathrm{~nm}$. Chymostatin (Peptide Institute Inc., Japan) was used as a reference compound.

\section{Cytotoxicity Assay}

HL-60 human leukemia cells (ATCC CCL-240) were grown in RPMI 1640 medium supplemented with $10 \%$ fetal calf serum in atmosphere containing $5 \% \mathrm{CO}_{2}$ at $37^{\circ} \mathrm{C}$ and $95 \%$ relative humidity. HL-60 cells were plated $\left(3 \times 10^{4}\right.$ cells/well in $100 \mu \mathrm{l}$ ) in 96-well microplates and incubated for 24 hours at $37^{\circ} \mathrm{C}$ with or without test compounds. After washing by centrifugation twice, fresh RPMI 1640 medium including 10\% Alamar Blue (Biosource, USA) was added and incubated for 3 hours. The viability of cells was estimated by fluorescence emission at wavelengths of Ex 544 nm/Em 590 nm

\section{Results}

\section{Taxonomy}

The cultural characteristics of the strain SPF-32629 grown at $25^{\circ} \mathrm{C}$ for 7 days were as follows. Colonies on MEA and PDA were white to vivid yellow and velvety with a diameter of $17 \sim 20 \mathrm{~mm}$. The colony reverse was vivid yellow on MEA and bright orange on PDA. Colonies on $\mathrm{G} 25 \mathrm{~N}$ were white and thin with a diameter of $3 \sim 4 \mathrm{~mm}$. The colony reverse was white. Colonies on CYA were white to deep reddish orange and velvety with a diameter of $9 \sim 10 \mathrm{~mm}$. The colony reverse was deep orange. Colonies on YSA were white to vivid yellow and velvety with a diameter of $20 \sim 21 \mathrm{~mm}$. The colony reverse was bright orange. Colonies on $\mathrm{OA}$ were white and velvety with a diameter of $26 \sim 27 \mathrm{~mm}$. The colony reverse was white. Production of conidia on OA was the most abundant among these six agar media. No soluble pigment was observed at $25^{\circ} \mathrm{C}$ for 7 days on these agar media, but bright orange pigment and exudate were observed after 14 days of incubation on CYA.

The morphological characteristics of strain SPF-32629 on $\mathrm{OA}$ at $25^{\circ} \mathrm{C}$ for 14 days were as follows. Conidiophores were formed from substrate and aerial hyphae, and penicilli were biverticillate. Metulae were 3 5 per conidiophore. Phialides were ampulliform and 3 5 per metula. Conidia were green, globose to subglobose, smooth-walled and produced in long chains on the tip of phialide. No teleomorph was observed even after 21 days of incubation on the six agar media mentioned above. From the above characteristics, the strain SPF-32629 was identified as a strain of the genus Penicillium LINK and named Penicillium sp. SPF-32629.
: SPF-32629A (1), $\mathbf{\square}:$ SPF-32629B (2)

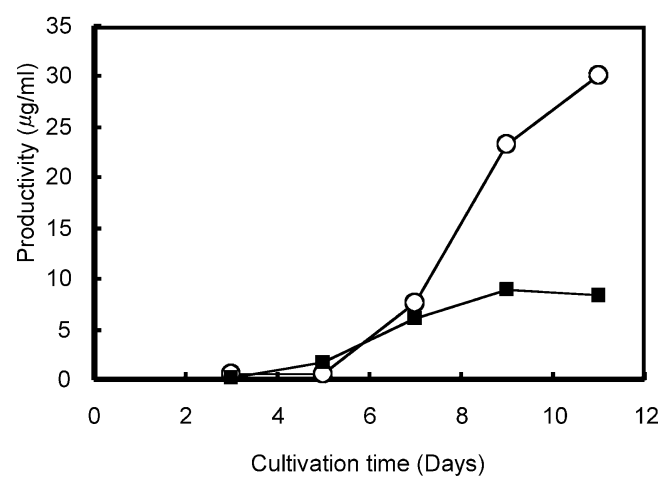

Fig. 2 Time course of production of SPF-32629A (1) and SPF-32629B (2) by Penicillium sp. SPF-32629 in a 2-liter Sakaguchi flask.

\section{Fermentation}

A time course of production of compounds $\mathbf{1}$ and $\mathbf{2}$ by Penicillium sp. SPF-32629 in a 2-liter Sakaguchi flask is shown in Fig. 2. Productivities of compounds $\mathbf{1}$ and $\mathbf{2}$ reached maximal yields of $30 \mu \mathrm{g} / \mathrm{ml}$ at day 11 and $8 \mu \mathrm{g} / \mathrm{ml}$ at day 9 , respectively.

\section{Isolation}

After 11 days of fermentation, 5 liters of acetone was added to the cultured broth (4.8 liters). The mixture was filtered and the filtrate was evaporated in vacuo to remove acetone. The aqueous solution was applied to a column $(500 \mathrm{ml})$ of Diaion HP-20 (Mitsubishi Chemical, Japan). The column was washed with water, $25 \%$ methanol, 50\% methanol and $75 \%$ methanol, and eluted with methanol and then with acetone. The acetone eluate (1.5 liters) was evaporated in vacuo to give a yellow crude extract $(500 \mathrm{mg})$. The crude extract was dissolved in $50 \mathrm{ml}$ of chloroform, and subjected to a column $(250 \mathrm{ml})$ of silica gel $60(70 \sim 230$ mesh, Merck, Germany). The column was washed with chloroform and then eluted with a mixture of chloroform methanol $(97: 3 \sim 70: 30, \mathrm{v} / \mathrm{v})$. Active fractions were pooled and evaporated in vacuo to give a yellow crude extract $(109 \mathrm{mg})$. The extract was dissolved in $3 \mathrm{ml}$ of a mixture of dimethylsulfoxide - methanol $(1: 1, \mathrm{v} / \mathrm{v})$ and applied to preparative HPLC equipped with Wakopak Wakosil-II5C18HG-Prep columns $(30 \mathrm{~mm}$ i.d. $\times 50 \mathrm{~mm}+$ $30 \mathrm{~mm}$ i.d. $\times 250 \mathrm{~mm}$ ). The elution was performed with aqueous $0.1 \%$ trifluoroacetic acid - acetonitrile $(45: 55, \mathrm{v} / \mathrm{v})$ at a flow rate of $10 \mathrm{ml} /$ minute and detection of UV absorption at $254 \mathrm{~nm}$. Active fractions (Rt: 84.0 minutes) were collected and the solvent was evaporated in vacuo to give $21.6 \mathrm{mg}$ of SPF-32629A (1) as yellow powder.

The methanol eluate (1.5 liters) from Diaion HP-20 
Table 1 Physico-chemical properties of $\mathbf{1}$ and $\mathbf{2}$

\begin{tabular}{|c|c|c|}
\hline & 1 & 2 \\
\hline Appearance & Pale yellow powder & Pale yellow powder \\
\hline Molecular formula & $\mathrm{C}_{17} \mathrm{H}_{19} \mathrm{NO}_{4}$ & $\mathrm{C}_{18} \mathrm{H}_{19} \mathrm{NO}_{6}$ \\
\hline FAB-MS $(m / z)$ & $302(\mathrm{M}+\mathrm{H})^{+}$ & $346(\mathrm{M}+\mathrm{H})^{+}$ \\
\hline \multicolumn{3}{|l|}{ HRFAB-MS $(m / z)$} \\
\hline Found: & $302.1393(\mathrm{M}+\mathrm{H})^{+}$ & $346.1292(\mathrm{M}+\mathrm{H})^{+}$ \\
\hline Calcd.: & 302.1392 & 346.1291 \\
\hline$U \vee \lambda_{\max }^{\mathrm{MeOH}} \mathrm{nm}(\varepsilon)$ & $206(22,200), 286(4,300)$ & $\begin{array}{l}203(16,500), 215 \operatorname{sh}(13,900), \\
303(6,300)\end{array}$ \\
\hline $\mathrm{IR} v_{\max }(\mathrm{KBr}) \mathrm{cm}^{-1}$ & $\begin{array}{l}3247,3099,2964,1748 \\
1643,1624,1458\end{array}$ & $\begin{array}{l}3247,3093,2964,1748 \\
1643,1617,1466\end{array}$ \\
\hline$[\alpha]_{D}^{25}(\mathrm{MeOH})$ & +26.4 (c 0.58$)$ & $+24.5(c 0.40)$ \\
\hline \multicolumn{3}{|l|}{ Solubility } \\
\hline Soluble: & $\mathrm{CHCl}_{3}$, Acetone & $\mathrm{CHCl}_{3}$, Acetone \\
\hline Insoluble: & $\mathrm{H}_{2} \mathrm{O}, n$-Hexane & $\mathrm{H}_{2} \mathrm{O}, n$-Hexane \\
\hline
\end{tabular}

mentioned above was evaporated in vacuo to give a yellow crude extract $(4.0 \mathrm{~g})$. The crude extract was dissolved in $50 \mathrm{ml}$ of methanol and applied to a column $(800 \mathrm{ml})$ of Sephadex LH-20 (Amersham Biosciences, USA), and the column was eluted with methanol. Active fractions $(1.5 \mathrm{~g})$ were evaporated in vacuo, dissolved in $15 \mathrm{ml}$ of chloroform, subjected to a column $(200 \mathrm{ml})$ of silica gel 60 (70 230 mesh) and washed with chloroform and then eluted with a mixture of chloroform-methanol (98:2 $80: 20, v / v)$. Fractions obtained with chloroform methanol $(95: 5, \mathrm{v} / \mathrm{v})$ were evaporated in vacuo to give a yellow solid (150 mg). The solid was dissolved in $2 \mathrm{ml}$ of methanol and applied to preparative HPLC mentioned above. The elution was performed with aqueous $0.1 \%$ trifluoroacetic acid - acetonitrile $(63: 37, \mathrm{v} / \mathrm{v})$ at a flow rate of $10 \mathrm{ml} / \mathrm{minute}$ and detection of UV absorption at $254 \mathrm{~nm}$. Active fractions (Rt: 69.5 minutes) were evaporated in vacuo to give $29.8 \mathrm{mg}$ of SPF-32629B (2) as yellow powder.

\section{Structure Elucidation}

The physico-chemical properties of $\mathbf{1}$ and $\mathbf{2}$ are summarized in Table 1. These data suggest that they are structurally related. The molecular formula of $\mathbf{1}$ was established as $\mathrm{C}_{17} \mathrm{H}_{19} \mathrm{NO}_{4}$ by HRFAB-MS and ${ }^{1} \mathrm{H}$ and ${ }^{13} \mathrm{C}$ NMR. The IR spectrum of $\mathbf{1}$ showed the presence of hydroxyl $\left(3247 \mathrm{~cm}^{-1}\right)$ and ester $\left(1748 \mathrm{~cm}^{-1}\right)$ groups. A 4hydroxy-2-pyridone chromophore was suggested in the IR (1643 and $\left.1624 \mathrm{~cm}^{-1}\right)$ and UV ( $\left.\lambda_{\max } 286 \mathrm{~nm}\right)$ spectra. The ${ }^{1} \mathrm{H}$ and ${ }^{13} \mathrm{C}$ NMR spectral data of $\mathbf{1}$ are summarized in Table 2 .

Analysis of the COSY and HMBC spectra of $\mathbf{1}$ revealed the presence of phenyl and isovaleryl ester groups (Fig. 3). The 4-hydroxy-2-pyridone moiety was confirmed on the basis of ${ }^{1} \mathrm{H}$ and ${ }^{13} \mathrm{C}$ chemical shifts and the $\mathrm{HMBC}$ correlations observed from the two aromatic protons at $\mathrm{H}-3$ and H-5 in 1. The methine group (C-7: $\left.\delta_{\mathrm{H}} 6.63, \delta_{\mathrm{C}} 72.8\right)$ was connected to the $\mathrm{C}-6$ of the pyridone ring on the basis of the HMBC correlations of $\mathrm{H}-7$ with C-5 and C-6 and of $\mathrm{H}-5$ with $\mathrm{C}-7$. The HMBC correlations of $\mathrm{H}-7$ with the phenyl carbon $\mathrm{C}-8$ and $\mathrm{C}-9$ and of the phenyl proton $\mathrm{H}-9$ with $\mathrm{C}-7$ revealed the connection of the phenyl group and the 4-hydroxy-2-pyridone via $\mathrm{C}-7$ methine group. The remaining isovaleryl ester group was located at $\mathrm{C}-7$ on the basis of the chemical shifts for $\mathrm{C}-7\left(\delta_{\mathrm{H}} 6.63, \delta_{\mathrm{C}} 72.8\right)$ and the $\mathrm{HMBC}$ correlations of $\mathrm{H}-7$ with isovaleryl carbonyl carbon $\mathrm{C}-14$. Using the combined data, the structure of $\mathbf{1}$ was determined to be (1,6-dihydro-4-hydroxy-6-oxo-2pyridinyl)(phenyl)methyl isovalerate as shown in Fig. 3.

The molecular formula of $\mathbf{2}$ was established as $\mathrm{C}_{18} \mathrm{H}_{19} \mathrm{NO}_{6}$ by HRFAB-MS and ${ }^{1} \mathrm{H}$ and ${ }^{13} \mathrm{C} \mathrm{NMR}$, differing from that of $\mathbf{1}$ by the addition of $\mathrm{CO}_{2}$ unit. The ${ }^{1} \mathrm{H}$ and ${ }^{13} \mathrm{C}$ NMR spectra of $\mathbf{2}$ were very similar to those of $\mathbf{1}$ except that 2 showed signals for an additional carbonyl group $\left(\delta_{\mathrm{C}}\right.$ $171.8)$ and a quaternary carbon $\left(\delta_{\mathrm{C}} 96.9\right)$ in place of the $\mathrm{C}$ 3 methine of the pyridone ring observed in $\mathbf{1}$. These ${ }^{1} \mathrm{H}$ and ${ }^{13} \mathrm{C}$ NMR data, together with the molecular formula, suggested that $\mathbf{2}$ was a carboxylated derivative of $\mathbf{1}$. The 4$\mathrm{OH}$ and $19-\mathrm{OH}$ resonances at $\delta_{\mathrm{H}} 13.46$ and $\delta_{\mathrm{H}} 14.19$ strongly suggested a peri-location hydrogen-bonding and this corroborates the bathochromic shift data $\left(\lambda_{\max } 2\right.$ : $303 \mathrm{~nm}$, 1: $286 \mathrm{~nm}$ ) that suggested the location of the carboxylic moiety at C-3 of the 4-hydroxy-2-pyridone moiety. This was confirmed by the HMBC correlations of 
Table $2{ }^{1} \mathrm{H}$ and ${ }^{13} \mathrm{C}$ NMR chemical shifts of $\mathbf{1}$ and $\mathbf{2}$

\begin{tabular}{|c|c|c|c|c|c|c|}
\hline \multirow{2}{*}{ No. } & \multicolumn{2}{|c|}{1 (in $\left.\mathrm{CDCl}_{3}\right)$} & \multicolumn{2}{|c|}{2 (in $\mathrm{CDCl}_{3}$ ) } & \multicolumn{2}{|c|}{2 (in acetone- $d_{6}$ ) } \\
\hline & ${ }^{13} \mathrm{C}$ & ${ }^{1} \mathrm{H}(J=\mathrm{Hz})$ & ${ }^{13} \mathrm{C}$ & ${ }^{1} \mathrm{H}(J=\mathrm{Hz})$ & ${ }^{13} \mathrm{C}$ & ${ }^{1} \mathrm{H}(\mathrm{J}=\mathrm{Hz})$ \\
\hline 2 & 164.4 & & 166.0 & & 166.4 & \\
\hline 3 & 97.7 & $6.09(1 \mathrm{H}, \mathrm{s})$ & 96.9 & & 96.7 & \\
\hline 4 & 171.4 & & 174.9 & & 175.1 & \\
\hline 5 & 104.1 & $6.23(1 \mathrm{H}, \mathrm{s})$ & 101.4 & $6.26(1 \mathrm{H}, \mathrm{s})$ & 100.2 & $6.38(1 \mathrm{H}, \mathrm{s})$ \\
\hline 6 & 148.4 & & 151.1 & & 153.2 & \\
\hline 7 & 72.8 & $6.63(1 \mathrm{H}, \mathrm{s})$ & 72.7 & $6.63(1 \mathrm{H}, \mathrm{s})$ & 73.4 & $6.76(1 \mathrm{H}, \mathrm{s})$ \\
\hline 8 & 135.3 & & 134.7 & & 136.8 & \\
\hline 9,13 & 127.2 & $7.34(2 \mathrm{H}, \mathrm{m})$ & 127.3 & $7.38^{e}(2 \mathrm{H}, \mathrm{br} \mathrm{s})$ & 128.1 & $7.57(2 \mathrm{H}, \mathrm{d}, 6.3)$ \\
\hline 10,12 & 129.1 & $7.33(2 \mathrm{H}, \mathrm{m})$ & 129.3 & $7.38^{e}(2 \mathrm{H}, \mathrm{br} \mathrm{s})$ & 129.5 & $7.43^{h}(2 \mathrm{H}, \mathrm{d}, 6.3)$ \\
\hline 11 & 129.5 & $7.32(1 \mathrm{H}, \mathrm{m})$ & 129.9 & $7.38^{e}(1 \mathrm{H}, \mathrm{brs})$ & 129.8 & $7.43^{h}(1 \mathrm{H}, \mathrm{d}, 6.3)$ \\
\hline 14 & 172.1 & & 171.3 & & 171.4 & \\
\hline 15 & 43.0 & $2.32(2 \mathrm{H}, \mathrm{d}, 7.0)$ & 42.9 & $2.32(2 \mathrm{H}, \mathrm{br} \mathrm{s})$ & 43.3 & $2.41(2 \mathrm{H}, \mathrm{d}, 6.8)$ \\
\hline 16 & 25.6 & $2.08(1 \mathrm{H}, \mathrm{m})$ & 25.7 & $2.10(1 \mathrm{H}, \mathrm{br} \mathrm{s})$ & 26.3 & $2.15(1 \mathrm{H}, \mathrm{m})$ \\
\hline 17 & $22.3^{a}$ & $0.89^{b}(3 \mathrm{H}, \mathrm{d}, 6.7)$ & $22.3^{d}$ & $0.91^{f}(3 \mathrm{H}, \mathrm{brs})$ & $22.5^{g}$ & $0.92^{i}(3 \mathrm{H}, \mathrm{d}, 6.4)$ \\
\hline 18 & $22.2^{a}$ & $0.88^{b}(3 \mathrm{H}, \mathrm{d}, 6.7)$ & $22.3^{d}$ & $0.91^{f}(3 \mathrm{H}, \mathrm{br} \mathrm{s})$ & $22.5^{g}$ & $0.92^{i}(3 \mathrm{H}, \mathrm{d}, 6.4)$ \\
\hline 19 & & & 171.8 & & 172.8 & \\
\hline 1-NH & & $N^{c}$ & & $11.10(1 \mathrm{H}, \mathrm{br} \mathrm{s})$ & & ND \\
\hline $4-\mathrm{OH}$ & & ND & & $13.46(1 \mathrm{H}, \mathrm{br} \mathrm{s})$ & & $13.51(1 \mathrm{H}, \mathrm{brs})$ \\
\hline $19-\mathrm{OH}$ & & & & $14.19(1 \mathrm{H}, \mathrm{br} \mathrm{s})$ & & ND \\
\hline
\end{tabular}

${ }^{a, b}$ Assignments may be interchanged. ${ }^{c}$ Not determined. ${ }^{d-i}$ Overlapped.

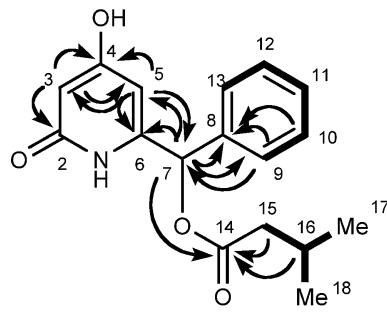

1

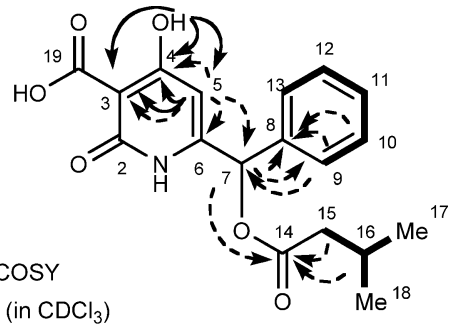

2

Fig. $3{ }^{1} \mathrm{H}^{1}{ }^{1} \mathrm{H}$ COSY and $\mathrm{HMBC}$ correlations observed in $\mathbf{1}$ and $\mathbf{2}$.

H-5 with C-3 and C-4 and of C-4 hydroxyl proton with C3, C-4 and C-5 in $\mathrm{CDCl}_{3}$ and of $\mathrm{H}-5$ with $\mathrm{C}-3, \mathrm{C}-4, \mathrm{C}-6$ and C-7 in acetone- $d_{6}$. Thus, 2 was determined to be the 3carboxylated derivative of $\mathbf{1}$.

Compounds 1 and 2 showed optical rotations of $+26.4^{\circ}$ and $+24.5^{\circ}$, respectively. Both compounds possess an asymmetric carbon at C-7. To analyze the optical purity, we used four types of chiral HPLC columns; Chiralpak AD-H, Chiralpak AS-H, Chiralcel OD-H and Chiralcel OJ-H, on several solvent systems. Both $\mathbf{1}$ and $\mathbf{2}$ exhibited a single peak under all conditions tested, suggesting compounds $\mathbf{1}$ and $\mathbf{2}$ are optically pure. The absolute configurations of $\mathbf{1}$ and 2 remain to be determined.

\section{Biological Activities}

Compounds $\mathbf{1}$ and $\mathbf{2}$ inhibited human chymase with the $\mathrm{IC}_{50}$ values of 0.25 and $0.42 \mu \mathrm{g} / \mathrm{ml}$, respectively (Table 3). Compound 1 inhibited both human cathepsin $\mathrm{G}$ and human elastase with the $\mathrm{IC}_{50}$ value of $4.9 \mu \mathrm{g} / \mathrm{ml}$ and showed $30 \%$ inhibition against human chymotrypsin at the concentration of $10 \mu \mathrm{g} / \mathrm{ml}$. Compound 2 inhibited human elastase with the $\mathrm{IC}_{50}$ value of $4.5 \mu \mathrm{g} / \mathrm{ml}$ but did not inhibit human chymotrypsin or human cathepsin $\mathrm{G}$ at the concentration of $10 \mu \mathrm{g} / \mathrm{ml}$. Therefore, $\mathbf{1}$ and $\mathbf{2}$ were specific chymase inhibitors. Moreover, $\mathbf{1}$ and $\mathbf{2}$ did not show cytotoxicity against HL60 human leukemia cells at the concentration of $10 \mu \mathrm{g} / \mathrm{ml}$. Chymostatin, a known inhibitor of serine 
Table $\mathbf{3}$ Inhibitory activities of $\mathbf{1}$ and $\mathbf{2}$ against four human serine proteases

\begin{tabular}{ccccc}
\hline & \multicolumn{3}{c}{$I \mathrm{C}_{50}(\mu \mathrm{g} / \mathrm{ml})$} \\
\cline { 2 - 4 } & Chymase & Chymotrypsin & Cathepsin $\mathrm{E}$ & Elastase \\
\hline $\mathbf{1}$ & 0.25 & $>10$ & 4.9 & 4.9 \\
$\mathbf{2}$ & 0.42 & $>10$ & $>10$ & 4.5 \\
Chymostatin & 0.005 & 0.003 & 0.057 & $>10$ \\
\hline
\end{tabular}

proteases, was more potent than $\mathbf{1}$ and $\mathbf{2}$, but less specific.

\section{Discussion}

In the course of our screening for human chymase inhibitors, we discovered two novel compounds, SPF32629A (1) and B (2), from the cultured broth of Penicillium sp. SPF-32629. Although chymostatin showed very potent inhibition against human chymase with the $\mathrm{IC}_{50}$ value of $0.005 \mu \mathrm{g} / \mathrm{ml}$, it also inhibited human chymotrypsin to the same degree. Compounds $\mathbf{1}$ and $\mathbf{2}$ showed at least 20 times higher selectivity against human chymase than human chymotrypsin. Compound $\mathbf{1}$ showed relatively higher potency to inhibit human chymase than $\mathbf{2}$, which was the carboxylated derivative of $\mathbf{1}$.

Recently, SF2809 compounds have been isolated as specific human chymase inhibitors from Dactylosporangium sp. [9, 10]. Compounds $\mathbf{1}$ and $\mathbf{2}$ structurally resemble SF2809-V and VI in that they possess a phenyl group and a hydroxypyridone moiety and an asymmetric methine. SF2809-V has been reported to be racemic. Our compounds 1 and $\mathbf{2}$ seem to be optically pure as analyzed by chiral HPLC though their absolute configurations remain to be established.

\section{References}

1. Wang Z, Walter M, Selwood T, Rubin H, Schechter NM. Recombinant expression of human mast cell proteases chymase and tryptase. Biol Chem 379: 167-174 (1998)

2. Urata H, Kinoshita A, Misono KS, Bumpus FM, Husain A. Identification of a highly specific chymase as the major angiotensin II-forming enzyme in the human heart. J Biol Chem 265: 22348-22357 (1990)

3. Sukenaga Y, Kamoshita K, Takai S, Miyazaki M. Development and application of the chymase inhibitor as an anti-tissue-remodeling drug: myocardial infarction and some other possibilities. Jpn J Pharmacol 90: 218-222 (2002)

4. Lee $\mathrm{M}$, von Eckardstein A, Lindstedt L, Assmann G,
Kovanen PT. Depletion of pre beta $1 \mathrm{LpA} 1$ and LpA4 particles by mast cell chymase reduces cholesterol efflux from macropharge foam cells induced by plasma. Arterioscler Thromb Vasc Biol 19: 1066-1074 (1999)

5. He S, Gaca MD, McEuen AR, Walls AF. Inhibitors of chymase as mast cell-stabilizing agents: contribution of chymase in the activation of human mast cells. J Pharmacol Exp Ther 291: 517-523 (1999)

6. Takai S, Shiota N, Jin D, Miyazaki M. Chymase processes big-endothelin-2 to endothelin-2-(1-31) that induces contractile responses in the isolated monkey trachea. Eur J Pharmacol 358: 229-233 (1998)

7. Mizutani H, Schechter N, Lazarus G, Black RA, Kupper TS. Rapid and specific conversion of precursor interleukin 1 beta (IL-1 beta) to an active IL-1 species by human mast cell chymase. J Exp Med 174: 821-825 (1991)

8) Saarinen J, Kalkkinen N, Welgus HG, Kovanen PT. Activation of human interstitial procollagenase through direct cleavage of the Leu83-The 84 bond by mast cell chymase. J Biol Chem 269: 18134-18140 (1994)

9. Tani M, Gyobu Y, Sasaki T, Takenouchi O, Kawamura T, Kamimura T, Harada T. SF2809 compounds, novel chymase inhibitors from Dactylosporangium sp. 1. Taxonomy, fermentation, isolation and biological properties. J Antibiot 57: 83-88 (2004)

10. Tani M, Hariyama K, Gyobu Y, Sasaki T, Takenouchi O, Kawamura T, Kamimura T, Harada T. SF2809 compounds, novel chymase inhibitors from Dactylosporangium sp. 2. Structural elucidation. J Antibiot 57: 89-96 (2004)

11. Pitt JI. The genus Penicillium and its teleomorphic states Eupenicillium and Talaromyces. Academic Press, New York (1979)

12. Nippon Shikisai Kenkyuusyo (Ed.): Color Tone Manual. Nippon Shikiken Jigyo Co., Tokyo (1973)

13. Sawada H, Yokosawa H, Hoshi M, Ishii S. Ascidian sperm chymotrypsin-like enzyme; participation in fertilization. Experientia 39: 377-378 (1983)

14. Castillo MJ, Nakajima K, Zimmerman M, Powers JC. Sensitive substrates for human leukocyte and porcine pancreatic elastase: a study of the merits of various chromophoric and fluorogenic leaving groups in assays for serine proteases. Anal Biochem 99: 53-64 (1979) 